\title{
Adat Penal Decision in The Indonesia Legal Practice
}

\author{
Maryano $^{1}$, Lilik Mulyadi ${ }^{2}$, Muhammad Ogan $^{3}$ \\ \{maryano.myn@gmail.com\} \\ Doctor of Law, Universitas Jayabaya, Jakarta, Indonesia
}

\begin{abstract}
The broad scope and dimensions of customary law are regulated in legal instruments, both national and international instruments. In terms of its substance, customary law can be categorized into customary civil law, customary state constitutional law, customary criminal law. Some terms have been derived from customary law including customary criminal law, customary offenses, customary violation law or criminal customary law for the forerunner. Seen from its source, customary criminal/civil law were developed from both written and unwritten sources. In this normative juridical research, legal materials were collected through identification and inventory of primary, secondary and tertiary legal materials. The legal materials were then normatively analyzed, which results showed that the presence of Customary Criminal Law in Indonesia is "there but not there". Its legality principle as stated in the normative perspective of Emergencies Act number 1 of 1951 explains that legislative policies are sectoral and the jurisprudence is under the authority of the Indonesian Supreme Court. In fact, many decisions have been made by Indonesian judiciary institutions on customary criminal cases and customary civil cases.
\end{abstract}

Keywords: Customary Law, Customary Court, Customary Crime

\section{Introduction}

In principle, the terminology of Adat law (customary law) was first proposed by Snouck Hurgronye and used as a juridical technical terminology before further popularized by van Vollenhoven. Then, the terms of customary law of the Dutch East Indies Period were regulated by the provisions in, for example, Article 11 Algemene Bepalingen van Wetgeving voor Indonesia $(\mathrm{AB})$ under a terminology of godsdientige wetten, volksinstelingen en gebruiken, Article 75 paragraph 3 Reglement op het Beleid der Regeling van Nederlands Indie (RR) under a terminology of Instellingen en gebruiken des volks, Article 128 Wet op de Staatsinrichting van Nederlandsch Indie or Indische Staatsregeling (IS) with terminology godsdientige wetten en oude herkomsten, and colonial provision in 1929 Number 221 in conjunction with Number 487. In the last regulation, the term Adatrecht was used for the last time.

Besides recognizing the national legal instruments, such law is also regulated by its international counterparts. The provisions of Article 15 paragraph (2) of the International Covenant on Civil and Political Rights (ICCPR) states that "nothing in this article shall prejudice the trial and punishment of any person for any act or omission which, at the time when it was committed, was criminal according to the general principles of law recognized by the community of nations." Then the recommendation from the United Nations (UN) Congress on "The Prevention of Crime and the Treatment of Offenders" stated that the criminal law system that had existed in several countries (especially those originating/ imported from foreign law during the colonial era) are "obsolete and unjust" and "outmoded and unreal" (outdated and 
irrelevant with the current situation). The reason is that the legal system in some countries is not rooted in cultural values, and there is a discrepancy with the aspirations of society and generally unresponsive to contemporary social needs. The UN Congress stated this condition as a contributing factor to the occurrence of crimes.

The scope and dimensions of customary law as in that context are then very broad within the legal instruments, both national and international level. In addition, a form of customary law can vary in its substantive dimensions, such as in aspects of civil law, constitutional law, criminal law (delictentrecht), and the like. All of which has roots in the customary law, both written and unwritten. Strictly speaking, unwritten sources that can constitute habits and bring it into existence are followed and accustomed consistently throughout times by those who adhered to them. As for the written legal sources, it can be exemplified as followed; the Ciwasasana or Purwadhigama Book that dated back to the 10th during the reign of King Dharmawangsa, the Book of Gajahmada, the Book of Simbur Cahaya from Palembang, the Book of Kuntara RajaNiti from Lampung, the Lontara "ade" Book from South Sulawesi, the Book of Adi Religion, the Book of Manawa Dharma Sastra, the book of Awig-Awig in Bali and all regulations written on palm leaves, leather or other materials and so on (Lilik Mulyadi, 2010: 2).

\section{Results and Discussion}

\section{Adat Court Between 'Existence' and 'Inexistence'}

The Adat court in the society which still adheres to the Adat law in Indonesia goes by the name like "sidang Adat," "para-para Adat," "pokara Adat," or "rapat Adat" depending on the local language. The technical juridical term refers to Law Number 21 of 2001 concerning the Special Autonomy for the Papua Province. The exposition of Article 9 paragraph 2 on section $\mathrm{d}$ in Law number 18 of 2004 concerning Plantation mentions "the existence of regulatory body and legal instrument pertaining the Adat court that must still be adhered." The exposition is also in Law number 1 of 1951 concerning the Temporary Actions to Assemble Unity of Power Structure and Civil Court Event Article 67 paragraph 1 section 4 and Law number 41 of 1999 jo. Law number 19 of 2004 concerning Forestry mentions, "the existence of regulatory body and legal instrument, pertaining Adat that must still be adhered."

However, as time progresses, what makes Adat law falls into the spectrum of "existence" and "inexistence" is due to the complexity of change and societal dynamic and the nature of partiality from the authority that creates the constitutional foundation legislative policy. There are five argumentations to be addressed in contextualizing because such an issue appears.

First, consideration is taken from the dimension of its formal legal principle and material legal principle. Basically, the legal principle can be legaliteinbeginsel, non-retroactive, de la legalite, or ex post facto law. The condition of legal principle in Article number 1 paragraph 1 from the Penal Code states that: "There shall be no punishment except the power endowed by the Penal Code that proceeded it" (Geen feit is strafbaar dan uit kracht van een daaran voorafgegane wetteljke strafbepaling). If both formal- and material-legal principles are combined, they should be integrally implemented within the existing constitution. While the formal legal principle regulates that a prosecution can occur on the basic legal principle if a specific law concerning that issue is already regulated in the law before the action is done, the base material legal principle for proceeding an offense is an unwritten law within the societyor known as the Adat law. 
Barda Nawawi Arief stated that the formulation of the principle of formal legality in Article 1 of the Criminal Code regulates that unwritten laws or laws existing in society cannot be the source of positive law. In other words, the existence of Article 1 of the Criminal Code is as if an unwritten criminal law that lives or has existed in society is often "put to sleep or put to death." During the colonial era, the unwritten criminal law was dormant to accord with the Dutch legal politics. However, after the independence, the policy needed to be rethought. Even with Article 1 of the Criminal Code, these unwritten law/ living laws were never fully explored and revealed on the surface, especially in the practice of criminal justice and in academic studies in universities. Furthermore, it means that the "jurisprudential tradition" and "academic/scientific tradition" regarding the unwritten criminal law were underdeveloped. If there was a development, it is only in a very limited or incomplete capacity (Barda Nawawi Arief, 1994: 25).

The basic conclusion from what is explained above is that the legality principle as stipulated in Article 1 of the Criminal Code is indeed one of the fundamental principles that must be maintained. However, its use must be wise and prudent lest it backfires. It would be tragic and heart-breaking if, under the pretext of Article 1 of the Criminal Code, the existing legal values in society cannot be properly channelled or even completely rejected. As such, there would also be a tragedy if the values of Adat law at the community level proceed unrecognized. It would be like killing their people with the weapons of former colonizers (through Article 1 of the Criminal Code / WvS). (Surojo Wignjodipuro, 1979: 298).

Second, reviewed from the perspective of Law Number 1 of 1951, where the existence of the Adat Court began to be unrecognized and abolished, and reviewed after the Fundamental Law of Judicial Power (The Law Number 14 of 1970) was codified and amended by The Law Number 35 of 1999, Law Number 4 of 2004, and Law Number 48 of 2009, Adat court is not recognized anymore. In the provisions of Article 1 paragraph (2) of The Law drt 1 of 1951, it is stated that "gradually, Minister of Justice will gradually determine it to be abolished ... all Adat Courts (Inheemse rechtspraak in rechtstreekbestuurd gebied) except for the religious court if, according to living law, it is a separate part of the Adat court." Furthermore, the authentic explanation of the article stated that the basis for the consideration of the abolition of the Adat judiciary was because it did not meet the requirement as a desired legal instrument by the UUDS and certainly unwanted by the people.

However, the abolition of Adat courts in that context does not essentially eliminate other types of Adat courts, namely village courts (dorpjustitie). These aspects and dimensions have their starting point under the provisions of Article 1 paragraph (3) of Law drt 1 of 1951. It emphasizes that "the provisions referred to in paragraph (1) do not reduce the power of rights that has been granted to judges in the villages as referred to in article $3 a$ Rechterlijke Organisatie". The context above implies and explicitly determines that the abolished Adat judiciary on the Emergency Law was that of in the sense of inheemsche rechtspraak, while the authority of the Adat court exercised by the chiefs of the Adat law community unit at the village court (dorpjustitie) continued.

Previously, during the Dutch colonial era, Adat Court was known in two forms: the Adat Court (Inheemsche rechtspraak) for the indigenous community and Village Court (Dorpjustitie). This dimension continued during the Japanese occupation era. Adat courts were still recognized and continued, even though Law Number 14 of 1942 (amended by Law Number 34 of 1942) simplified the judicial system by eliminating the distinction between gubernemen and courts for the indigenous community. Sudikno Mertokusumo stated that in Sumatra, Adat courts were firmly declared to remain valid and asserted based on Article 1 of the law concerning 
Regulations of Judges and Court (Sjihososjiki-rei) within Tomi-seirei-otsu No. 40 dated December 1, 1943. (Sudikno Mertokusumo, 2011: 13-41).

Third, examined from a juridical, theoretical, sociological, and philosophical perspective, the existence of Adat court must be recognized. These aspects and dimensions are based on the provisions of Article 18B paragraph (2), Article 28I paragraph (3) and Article 24 paragraph (3) of the 1945 Constitution of the Republic of Indonesia, MPR Decree Number IX/ MPR/ 2001, Law Number 17 of 2007, and Presidential Decree Number 7 of 2005. Article 18B paragraph (2) states that "the state recognizes and respects indigenous peoples and their traditional rights as long as they remain alive and in accordance with the development of society and the principles of the Unitary State of the Republic of Indonesia, which are regulated in The Law." Article 28I paragraph (3) states, "the cultural identity and rights of traditional communities are respected in accordance with the times and civilizations." Article 24 paragraph (3) states, "other institutions whose functions are related to judicial power are regulated in the law."

MPR Decree No. IX / MPR / 2001 on Agrarian Reform and Natural Resources Management stipulates that agrarian reform and natural resource management must be implemented in accordance with the following principles: 1). respecting the rule of law by accommodating diversity in legal unification; and 2) recognizing, respecting, and protecting the rights of indigenous peoples and the nation's cultural diversity regarding the agrarian or natural resources." Law Number 17 of 2007 concerning the National Long-Term Development Plan 2005-2025 (RP JPN 2005-2025 states that 1) the direction of legal development must take into account the plurality of the prevailing legal order and 2) recognition of local wisdom and customary rights over natural resources.” Presidential Regulation Number 7 of 2005 concerning the 2004-2009 National Medium-Term Development Plan (RP JMN 2004-2009) states that 1) respecting and strengthening local wisdom and customary law to create orderly legislation and 2) increasing the institutional capacity of natural resource and environmental management at the central and regional levels, which include organizations by the indigenous peoples.

These provisions show that indigenous peoples' existence and their traditional rights are regulated, recognized, and respected. Furthermore, human rights include respect for cultural identity, diversity in national culture, and traditional communities' rights for as long as they remain on the radar of civilizations. The recognition of the existence of judicial bodies is also part of the judicial power as regulated in law. The dimensions of these provisions are examined from a juridical perspective, meaning that constitutionally legal politics recognizes the traditional rights of Adat law communities in casu of the Adat courts.

From the philosophical perspective, it is assumed that the respect and recognition for and existence of human values and human rights by the state, including the right to exercise judicial power, must also be reflected in the legal politics of the Indonesian judiciary. From a sociological perspective, the Adat court, as part of the traditional rights of indigenous peoples, remains active in society. Yet, this sociological fact is relatively irrelevant in the eyes of legal politics of judicial power. From the theoretical perspective, the respect and recognition for and existence of traditional rights of indigenous peoples should be followed up by the state with national legislation. The logical consequence of this dimension means that the recognition of traditional rights of Adat law communities in the 1945 Constitution of the Republic of Indonesia must imperatively be recognized in law. However it is otherwise.

Fourth, at the level of local legislative policies, the existence of Adat courts is still recognized. At present, Adat courts are recognized in Law Number 21 of 2001 concerning Special Autonomy for Papua Province and the Nangroe Aceh Darussalam region referred to in Law Number 11 of 2006 concerning Aceh Government and their active implementation of Adat court known as the Gampong Adat Court or Peaceful Justice. In Papua, the provisions of Article 
50 paragraph (1) states that "the judiciary exercises judicial power in the Papua Province in accordance with statutory regulations." Paragraph 2 states, "in addition to the judicial power as referred to in paragraph 1, there exists Adat court in certain Customary Law communities." Moreover, Article 9 paragraph 3 of the Papua Province Special Regional Regulation Number 20 of 2008 concerning Customary Courts in Papua states that "Adat judges administer the administration of Customary courts."

Fifth, however, even though national formulating policies do not recognize the existence of Adat courts, actual and factual policies are applied through the jurisprudence of the Supreme Court of the Republic of Indonesia, which by effect means Adat courts is practically and technically valid. For example, in the Decision of the Supreme Court of the Republic of Indonesia Number 1644 K/ Pid / 1988 on May 15, 1991, in the ratio decidendi, the decision states that if a person violates Adat law and the Adat Chief provide reactions (Adat sanctions or Adat 'medicine'), the person in question cannot be filed again (for the second time) as a defendant in a trial by the State Court (District Court) with the same charges of violating Adat law and be sanctioned imprisonment according to the provisions of the Criminal Code (Article 5 paragraph (3) sub b of Law drt No. 1 of 1951). Thus, in such circumstances, the transfer of case files and demands of the Prosecutor's Office at the District Court must be declared unacceptable (niet ontvankelijk Verklaard).

The basic conclusion from the supreme court's jurisprudence determines that the Supreme Court of the Republic of Indonesia as the Supreme Judiciary Body in Indonesia still respects the decision of the Adat Chief (Pemuka Adat), which imposes sanctions against violators of the norms of Adat law. The general judiciary cannot justify trying a second time against the offenders of the Adat law by way of imprisonment (as exemplified in Article 5 paragraph (3) sub b of Law No. 1 of 1951 in conjunction with articles of the Criminal Code). Therefore, the logical consequence is if the Adat Chief has never given any form of Adat sanctions, the judges of the state judiciary are fully authorized to prosecute them based on the provisions of Article 5 paragraph (3) sub-b of Law No. 1 year. 1951 in conjunction with articles of the Criminal Code.

\section{Adat Penal Decision in The Legal Practice of Indonesia}

The Supreme Court's Decision of the Republic of Indonesia Number 666 K / Pid / 1984, February 23, 1985. The Supreme Court's Decision of the Republic of Indonesia Number 666 K/ Pid/ 1984 on February 23, 1985, was a case originating from the Luwuk District Court Decision Number 27/ Pid /1983 in conjunction with the Palu High Court Decision Number 6/ Pid/ 1984 dated April 9, 1984. Luwuk District Court Number 27/ Pid/ 1983 concerning a case of extramarital sexual relations.

At the district court level, the judge decided that the defendant had violated the living law in the Banggai Regency, Central Sulawesi, based on Article 5 paragraph 3 sub-b of the Darts Law Number 1 of 1951, which contained the following elements:

a. The first element is an act that violates the living law.

b. The second element is these violations have no equality in the Criminal Code.

c. The third element of the offense is still valid for the subjects and the people concerned.

The ratio decidendi of the decision of the Luwuk District Court Number 27/ Pid/ 1983 stated that the act of extramarital sexual relations by a man (a resident of Banggai) with an adult woman which resulted in the woman's pregnancy was deemed to violate living law and violated the norm of decency. The act also violated morality because the act did not qualify as an offense by the Criminal Code. Therefore, the judge decided that the defendant had committed a crime which, according to living law, should be considered a criminal act but which has nothing in common in the Civil Criminal Code. 
Afterward, with the Luwuk District Court Decision Number 27/ Pid/ 1983 and strengthened by the Palu High Court Decision Number 6/ Pid/ 1984 dated April 9, 1984, driven by a sense of justice of the people who considered the offense as a criminal act, the judge decided the defendant had committed the crime of fornication. However, by the Supreme Court through the Decision of the Supreme Court of the Republic of Indonesia Number 666 K/ Pid/ 1984 on February 23, 1985, the High Court's decision was corrected as a qualification where the act committed by the defendant was an act categorized as an act of adultery according to Adat law.

Basically, the Decision of the Supreme Court of the Republic of Indonesia Number 666 K/ Pid/ 1984 on February 23, 1985, did not stipulate Adat sanctions for violations committed by the defendant. Judges of judex facti (District Court) and jurisprudence judges (Supreme Court of the Republic of Indonesia) directly determine the sentence for the defendant through criminal sanctions. Strictly speaking, in other words, what was imposed by the judge was not a substitute sentence.

Regarding the context of the decision above, H.R. Otje Salman Soemadiningrat stated that there are still many judges who base their decisions on the Adat criminal law or think that the Adat criminal law is still valid. This is because, first, Adat law does not recognize a strict separation between criminal law and civil (private) law. That means those two aspects are considered related. There is no difference in the principle of the procedure for the settlement of cases of Adat violations. If there is a violation, the legal functionaries (Adat Chief) have the authority to take concrete actions, either on their own initiative or based on the injured party's complaint. (H.R. Otje Salman Soemadiningrat, 2002: 157-159)

This is solely done to determine the law (verklaring van recht) in the form of Adat sanctions (Adatreactie) which are deemed suitable to correct the violated Adat law. The offender can carry out this form of sanction by paying compensation to the party affected by the violation (rechtsherstel) or paying Adat money to the affected party and/or the community.

Finally, every Adat law is always related to or conceives elements of culture and belief (religious magic) that live in the society. Likewise, in the case of sex, it is considered sacred and taboo (Pemali in Javanese) and only permitted by a married couple. In such a perspective, in every living law, what does not contain magical religious elements or is not related to cultural elements and beliefs that grow in society cannot be considered Adat law.

The decision of the Supreme Court of the Republic of Indonesia Number 1644 K / Pid / 1988 dated May 15, 1991. The Decision of the Supreme Court of the Republic of Indonesia Number 1644 K / Pid / 1988 on May 15, 1991, which was a case originating from the Kendari District Court Decision Number 17 / Pid / B / 1987 / PN.Kdl dated June 15, 1987, is in conjunction with the Decision of the Southeast Sulawesi Supreme Court Number 32/ Pid/ B/ 1987/ PT Sultra on November 11, 1987.

The case posited by the Kendari District Court Decision Number 17/ Pid/ B/ 1987 / PN.Kdl, on June 15, 1987, stated that a defendant had committed immoral acts in Parauna Village, Unaaha District, Kendari. As a result of this deed, the Chief of Tolake handled the incident in accordance with his traditional custom. The Chief decided that the perpetrator had violated the customary norms of decency, and its form of Adat sanction was Prohala, by which the perpetrator had to pay a buffalo and one piece of Kain Kaci, which he was gladly obliged to do.

However, the police investigated the matter and then submitted it to the prosecutor's office. By then, the prosecutor transferred the case to the Kendari district court. There, the defendant was charged with violating a criminal offense in the form of a primary charge of violating Article 53 jo, and Article 285 of the Criminal Code. Also, the defendant was charged with subsidiary charges in the form of violating Article 281 paragraph 1of the Criminal Code and 
with more subsidiary charges due to violating Article 5 paragraph 3 sub b of the dart Law Number 1 of 1951.

Then the Kendari District Court Decision Number 17 / Pid / B/ 1987/ PN.Kdl, on June 15, 1987 , stated that the defendant was proven legally and convincingly guilty of committing the customary crime of "rape" as in the subsidiary indictment with the deciding ratio of the verdict as follows:

a. the Kendari District Court judge rejected the defendant's plead, who stated that his Chief had sentenced him through Prohala. It means that he was supposedly exempted from being tried again at the state court on the criminal charges (ne bis in idem).

b. The rejection was based on the Law on Judicial Power provisions that must be the sole judiciary institution to authorize criminal cases at the District Court.

c. The judge assessed that the element of the primary indictment that violated Article 53 in conjunction with Article 285 of the Criminal Code as well as the subsidiary charge of violating Article 281 paragraph (1) 1e of the Criminal Code, was not proven. What was proven was that the charges were more subordinate and violated Article 5 paragraph 3 sub b of the Darts Law Number 1 of 1951. According to living law, it stated that an act must be considered a criminal act and which has no comparison in the Criminal Code shall be deemed to be punishable by the same penalty as the comparable punishment that most closely resembles the criminal act.

Then on the Kendari District Court Decision Number 17/ Pid/ B/ 1987 / PN.Kdl dated June 15,1987 , the defendant submitted an appeal examination to the Southeast Sulawesi High Court. Based on the appeal, the Decision of the Southeast Sulawesi High Court Number 32 / Pid / B / 1987 / PT Sultra dated November 11, 1987, strengthened the District Court's decision by simply improving the qualifications in which the defendant was sentenced for being guilty of "Siri Adat crime" with a ratio decidendi of the decisions as follows:

a. According to the living Adat law in the Tolake community, the defendant's act was very despicably offending the Siri norm and thus must be subjected to the Adat law. That is, the injured party (Tomasiri) might suffer for their ordeal and result in casualties (Siri Ripoamateng or Siri dipomate)

b. The Adat offense violated by the defendant (Siri Ripoamateng or Siri dipomate), violated decency and undermined the dignity of the woman's family

c. The Adat criminal acts committed by the defendant have no comparison in the Criminal Code, and therefore according to the judge, the defendant must be sentenced for violating Adat law based on the provisions of Article 5 paragraph (3) sub b of the Darts Law Number 1 of 1951.

On the Decision of the Southeast Sulawesi High Court Number 32/ Pid/ B/ 1987/ PT Sultra dated November 11, 1987, the defendant declared an appeal to the Supreme Court of the Republic of Indonesia. After examining this case, the Decision of the Supreme Court of the Republic of Indonesia Number 1644 K / Pid / 1988 dated May 15, 1991, in essence, stated that the Supreme Court had a judex factie opinion that the law had been inappropriately implemented so that the decision had to be annulled and then the Indonesian Supreme Court had to proceed the case themselves.

Essentially, the Supreme Court decision is based on the following legal considerations:

a. The defendant had already obliged and indulged in the desire of his Chief by paying a buffalo and one piece of cloth after he committed the Adat violation. 
b. The Adat punishment was commensurate with the guilt of the convicted person so that according to the provisions of Article 5 paragraph (3) sub b of the Drt Law Number 1 of 1951 , the defendant could not be sentenced at the state court.

c. Based on the considerations above, the Supreme Court then canceled the decision of the Southeast Sulawesi High Court and tried the case itself by stating that the demands of the public prosecutor at the Kendari district attorney were unacceptable and resulted in the burden of court fees on the state.

The basic conclusion from the Supreme Court's jurisprudence determines that the Supreme Court of the Republic of Indonesia as the Supreme Judiciary Body in Indonesia still respects the decision of the Customary Chief (Pemuka Adat), which imposes Adat sanctions against violators of Customary law norms. The General Judiciary cannot justify trying a defendant for the second time against the Adat law by way of imprisonment (Article 5 paragraph (3) sub b of Law No. 1 of 1951 in conjunction with articles of the Criminal Code). Therefore, the logical consequence can be said that if the Adat Chief never granted a sanction based on his traditional custom to the offender of the Adat law, then the state judge is fully authorized to judge the offender based on the provisions of Article 5 paragraph (3) sub-b of Law No. 1 year. 1951 in conjunction with articles of the Criminal Code.

Denpasar District Court Decision Number 104 / PN.Dps / Pid / 1980, Denpasar District Court Decision Number 2/ Pid.B/ 1985/ PN.Dps, Klungkung District Court Decision Number 24/ Pid./ S/ 1992/ PN.KLK. and Denpasar District Court Decision Number 25/ Pid.B / 1986/ PN.Dps.

The decision in the context above violates the provisions of the Adat delict (offense), which was known as Lokika Sanggraha, which is specific to and only exists in Bali. Thus, if there is one party as the subject to such Adat law, then the delict is considered invalid, and thus, Lokika Sanggraha cannot be brought to existence.

As assessed from a technical juridical perspective, these decisions used the terminology from Sanggraha's Logic. However, it was relatively inaccurate because the correct one is supposed to be Lokika Sanggraha. Based on Article 359 of the Adiagama Book, Lokika Sanggraha originates from the Sanskrit language. Lokika comes from the word "laukika," which means common people or the populace, while Sanggraha comes from the word "Samgraha," which means grasp (in a broader sense), touch, or relationship. In the Javanese-Indonesian Dictionary, Lokika can mean society, population, world, custom (procedure), accusations, and charges. So, the term Sanggraha Logic is inappropriate since it contains the term "logic" that has a Latin root and completely adrift from its Sanskrit root. It, therefore, can be considered the trait of "misguided" language usage.

The dimension of Lokika Sanggraha is a customary offense regulated in the provisions of Article 359 of the Adiagama Book, the formulation of the Adat delict of Lokika Sanggraha is:

Malih lokika sanggraha, loewir ipoen, djadma mededemenan, sane mowani neherang deen ipoen, djening djirih patjang kesisipang, awanan ipoen ngererehang daja, saoebajan iloeh kesanggoepin ; wastoeraoeh ring papadoewantoengkas paksana, sane loeh ngakoe kasanggama, sane mowani nglisang mapaksa ngoetjapang dewek ipoen kaparikosa antoek iloeh, jan aspoenika patoet tetes terangang pisan, jan djati imowani menemenin wenang ipoen sisipang danda oetama sahasa 24.000 , poenika mawasta Lokia Sanggraha, oetjaping sastra.

Or roughly translated as such:

Lokika Sanggaraha: when two persons copulate, by which the man refuses to carry on due to fear of being blamed, then in his effort, he fulfills the promise of the woman until they are both in the court. There, the woman states a different claim, and the man tells the court that he 
was the one who was raped. If it is the case, it should be justly pursued. If the man is found out to be the rapist, he shall be punished with a fine 24.000,- that is what Lokika Sanggraha.

Article 359 of the Adiagama Book and the formulation of a seminar "Delik Adat Lokika Sanggraha" by the Faculty of Law at Udayana University on October 19, 1985, specified the general meaning of the Lokika Sanggraha customary offense as a romantic relationship between a man and a woman who are neither married and engage in premarital sexual intercourse with a marriage prospect yet one party violates the promise.

Based on that formulation, it essentially observes that the Lokika Sanggraha can be a formal offense when the element of pregnancy and unkept promise (the most important consideration in this Adat law) occur. The Lokika Sanggraha appeared in court due to the complaint by the woman. Thus, this Adat offense becomes delik aduan or litigious situation (Kracht-Delicten).

The Lokika Sanggraha occurs in judicial practice in Bali regularly. If examined in more detail, for the people of Bali, violating the Lokika Sanggraha is a criminal act that disturbs the sense of law and feelings of justice within the Indigenous community. It is considered as a disturbance of the cosmic balance between the natural and invisible. If it is inserted into the Criminal Code, the act itself may find incongruent as it is not regulated. In the provisions of Article 10 of the Criminal Code, the type of punishment in the form of "recovery of customary obligations" is unknown. If an offender of Lokika Sanggraha is in prison, the native Balinese may find it incomplete without being followed by "restoration of customary obligations" to restore the disturbed cosmos. Therefore, the material solution must also be followed by its immaterial counterparts that are religious in nature. The imposition of penalties in the Balinese Adat law aims to restore the disturbance of the balance of the cosmic universe between the natural (sekala) and the unseen (niskala) and, therefore, the Hindu aspect religious ceremonies is fundamental in it.

For example, it can be said that a Lokika Sanggraha was carried out in a holy place (Pura), then by the judge, the perpetrator was given a verdict following Article 5 paragraph 3 sub b of the Dart Law. Number 1 of 1951 in conjunction with Article 359 of the Adiagama Book, namely for 3 months in prison. However, this is not enough. According to Balinese Hindu tradition, a temple is a holy and sacred place, so in addition to imprisonment, the perpetrator must also be subject to hold a religious ceremony in that place so that the resentful and disturbed cosmos will "recover" again.

According to the Balinese view, such a solution is closely related to the conception of Hinduism itself, namely in the form of Tri Hita Karana or Three Things that cause happiness. Tri Hita Karana has dimensions in the form of Parhyangan (harmony of the relationship between the Creator and humans as the former's creation), Pawongan (the harmony of human relationships with one another), and Pelemahan (the harmony of the relationship between humans and their natural surroundings). These are the underlying things behind the settlement of the Lokika Sanggraha within the Balinese community should there be imprisonment if such Adat law is violated.

\section{Conclusion}

The Adat justice system in Indonesia is two-dimensional-between existence and inexistence. These dimensions can be examined from its legal principle, its normative perspective in Article 1 1951, and the legislative policy that is sectoral in nature and depending 
on the jurisprudence of the Indonesian Supreme Court. In the practice of sovereign law, there have been numerous verdicts assigned by the legal institution towards penal and civil Adat law.

\section{References}

[1] Arief, Barda Nawawi (1994) Beberapa Aspek Pengembangan Ilmu Hukum Pidana (Menyongsong Generasi Baru Hukum Pidana Indonesia), Pidana Pengukuhan Guru Besar, Semarang: Fakultas Hukum Universitas Diponegoro.

[2]

[3] ---------------, (2010) Kebijakan Legislatif Dalam Penanggulangan Kejahatan Dengan Pidana Penjara, Yogyakarta: Genta Publishing.

[5] Din, Mohd. (2010) Aspek Hukum Eksistensi Hukum Pidana Adat di Indonesia, Makalah Penelitian Eksistensi Hukum Pidana Adat di Indonesia: Pengkajian Asas, Teori, Norma, Praktik dan Prosedurnya di Banda Aceh, on 27-29 June 2010.

[6]

[7] Dinnen, Sinclair (2003) Interfaces Between Formal and Informal Justice System To Strengthen Access to Justice By Disadvantaged System, Makalah disampaikan dalam Practice In Action Workshop UNDP Asia-Pasific Rights and Justice Initiative, Ahungala Sri Langka, 19-21 November 2003

[8]

[9] Mertokusumo, Sudikno (2011) Sejarah Peradilan dan Perundang-undangannya di Indonesia Sejak 1942 dan Apakah Kemanfaatannya Bagi Kita Bangsa Indonesia, Yogyakarta: Universitas Atma Jaya. [10]

[11] Mulyadi, Lilik (2010) Makalah Penelitian Eksistensi Hukum Pidana Adat di Indonesia: Pengkajian Asas, Teori, Norma, Praktik dan Prosedurnya, untuk wilayah Pengadilan Tinggi Banda Aceh, Medan, Denpasar, Mataram dan Banjarmasin, bulan Juni-Juli.

[13] --------------, (1987) Delik Adat “Lokika Sanggraha“ Di Bali, MajalahVaria Peradilan, Jakarta: Penerbit IKAHI (Ikatan Hakim Indonesia).

[14] Sembayang, Mahmud (2009) Hukum Adat Rimba dan Hukum Positif, Prakarsa Rakyat, (Jakarta, Sinar Harapan Rakyat, 28 April 2009), melalui http://www.prakarsa[15] rakyat.org/artikel_kirim.php?aid+33984 accessed on 4 October 2013.

[16] Soemadiningrat, H.R. Otje Salman (2002) Rekonseptualisasi Hukum Adat Kontemporer, PT Bandung: Alumni.

[17] Wignjodipuro, Surojo (1979) Pengantar dan Azas-Azas Hukum Adat, Bandung: Alumni 